\title{
ASSOCIATION BETWEEN SENSORINEURAL HEARING LOSS AND TYPE II DIABETES MELLITUS
}

\section{Hari Krishna*.}

*Associate professor in the department of ENT, Viswabharthi Medical College, Kurnool, Andhra Pradesh, India.

\section{ABSTRACT}

Introduction: sensorineural hearing loss is usually common in diabetics. Microangiopathy and neuropathy are the main attributed caused for sensorineural hearing loss.

Objectives: planned to study the prevalence of sensorineural hearing loss(SNHL) among Type II DM patients and to study the association between age, duration of DM and HbA1C levels with SNHL in India.

Methodology: A cross-sectional study was done on 256 type II Diabetic patients who attended medicine OP. sensorineural hearing loss was measured using Pure tone audiometry and were classified according to WHO classification.

Results: $45.7 \%$ were males and $54.3 \%$ were females. $88.7 \%$ had bilateral SNHL. $17 \%$ had severe degree of SNHL. The prevalence of SNHL increased with advancement of age, increased duration of DM and poor glycaemic control.

Conclusion: There is a strong association between diabetes and SNHL. Hence proper glycemic control in diabetics must be ensured to prevent from complications.

KEY WORDS: Diabetes Mellitus, Glycaemic, Hearing loss, and Sensorineural.

Address for correspondence: Dr. Hari Krishna, Associate professor in the department of ENT, Viswabharthi medical college, Kurnool, Andhra Pradesh, India - 518467.

E-Mail: belagantiharireddy@gmail.com

\begin{tabular}{|c|c|c|}
\hline \multicolumn{3}{|c|}{ Online Access and Article Informtaion } \\
\hline \multirow{2}{*}{$\begin{array}{c}\text { Quick Response code } \\
\text { DOI: } 10.16965 / \text { ijims.2020.103 }\end{array}$} & \multicolumn{2}{|c|}{$\begin{array}{l}\text { International Journal of Integrative Medical Sciences } \\
\text { ISSN (P): } 2394 \text { - 6318. ISSN (E): } 2394 \text { - } 4137\end{array}$} \\
\hline & $\begin{array}{l}\text { Received: 05-02-2020 } \\
\text { Reviewed: 05-02-2020 }\end{array}$ & $\begin{array}{l}\text { Accepted: } 23-03-2020 \\
\text { Published: } 30-04-2020\end{array}$ \\
\hline Source of Funding: Self & \multicolumn{2}{|c|}{ Conflicts of interest: None } \\
\hline
\end{tabular}

\section{INTRODUCTION}

Diabetes mellitus (DM) is a disease caused due to a disorder in the endocrine pancreas, which, when not controlled causes numerous complications in multiple systems. One of the known complications is hearing loss which leads to decreased quality of life [1]. Hearing loss in DM is usually Bilateral and sensorineural [2]. According to the WHO reports, the prevalence of DM has nearly doubled in developed countries and the prevalence is increasing in middle and low income countries. The prevalence of hearing loss is alarming and it is expected to double by 2050 . WHO also states that around $60 \%$ of the hearing losses are due to preventable causes $[3,4]$. The suggested reason for sensorineural hearing loss(SNHL) in diabetes is diabetic angiopathy. Diffuse thickening of basal membranes of the vascular endothelium is the common pathogenesis in angiopathy which interferes with the cochlear blood supply thereby reducing nutrient transport which indirectly reduces blood flow in narrowed blood vessels causing secondary degeneration of eighth cranial nerve [5-7]. On the contrary, there are authors who report the possibility of early sensorineural loss due to multiple other factors and not due to DM [8-12]. 
Hence this study was planned to study the prevalence of sensorineural hearing loss(SNHL) among Type II DM patients and to study the association between age, duration of DM and $\mathrm{HbA1C}$ levels with SNHL in India.

\section{MATHODOLOGY}

256 known type II DM patients who attended the medicine OPD for regular diabetic consultation between October 2016 and October 2019 were included in the study after explaining about the study and getting prior informed consent. The patients who consented to participate were requested to attend ENT OPD at a particular time and date of their convenience and hearing loss was assessed.

\section{Inclusion criteria:}

1. Type II DM on oral hypoglycemic agents

\section{Patients between $31-70$ years of age}

3. No other systemic illness(hypertension, Coronary heart disease, Thyroid disorder, renal failure, etc.,)

\section{Tympanic Membrane intact on both sides.}

\section{Exclusion criteria:}

1. Family history of deafness,

2. History of chronic suppurative otitis media (CSOM), meningitis, head or ear trauma,

3. History of chicken pox, smallpox, malaria, jaundice, typhoid.

4. History of ear surgeries performed in the past, and

Table 1: Association between age and prevalence of Sensorineural hearing loss.

\begin{tabular}{|c|c|c|c|c|c|c|c|}
\hline \multirow{2}{*}{ Age group } & \multicolumn{2}{|c|}{ Diabetics } & \multicolumn{2}{|c|}{ Diabetics with SNHL } & \multirow{2}{*}{$\begin{array}{c}\text { Chi-square } \\
\text { value }\end{array}$} & \multirow{2}{*}{ P-Value } & \multirow{2}{*}{$\begin{array}{l}\text { Prevalence within } \\
\text { the age group }\end{array}$} \\
\hline & Frequency & $\%$ & Frequency & $\%$ & & & \\
\hline $31-40$ & 45 & 17.58 & 12 & 11.33 & \multirow{5}{*}{27.12} & \multirow{5}{*}{$<0.05$} & 26.67 \\
\hline $41-50$ & 78 & 30.47 & 21 & 19.81 & & & 26.92 \\
\hline $51-60$ & 80 & 31.25 & 35 & 33.01 & & & 43.75 \\
\hline $61-70$ & 53 & 20.7 & 38 & 35.85 & & & 71.7 \\
\hline Total & 256 & 100 & 106 & 100 & & & 41.4 \\
\hline
\end{tabular}

Table 2: Distribution of Study Population according to the degree of SNHL.

\begin{tabular}{|c|c|c|}
\hline Degree of SNHL & Frequency & Percentage \\
\hline Mild & 51 & 48.12 \\
\hline Moderate & 31 & 29.24 \\
\hline Moderately severe & 6 & 5.66 \\
\hline Severe & 18 & 16.98 \\
\hline Total & $\mathbf{1 0 6}$ & $\mathbf{1 0 0}$ \\
\hline
\end{tabular}
degree of SNHL while around $29 \%$ had moderate degree of SNHL while only $17 \%$ had severe degree of SNHL. (Table 2) complications.

As shown in table 3 , around $32.5 \%$ of study population had diabetes within 2-5 years while another $28.5 \%$ had diabetes within 2 years. Around $21.5 \%$ were diabetics for $5-10$ years. Around

$21.5 \%$ of study population had diabetes for more

5. History of ototoxic drug intake, chronic smoking, alcohol, radiotherapy, autoimmune diseases, and systemic diseases such as hypertension, cardiac diseases and renal failure and occupational noise exposure.

Threshold determination is done for both air and bone conduction using pure tone audiogram (PTA). The random, fasting and postprandial blood glucose levels, and hemoglobin A1C were estimated to find the glycemic status and serum urea and creatinine levels to rule out diabetic nephropathy. To assess the degree of hearing loss, WHO classification (1980) on the basis of PTA taking the average of the thresholds of hearing for frequencies of 500,1000, and 2000 is used. Degree of hearing loss - mild: 26$40 \mathrm{~dB}$, moderate: $41-55 \mathrm{~dB}$, moderately severe: 56-70 dB, severe: $71-90 \mathrm{~dB}$, and profound: more than $90 \mathrm{~dB}$.

\section{RESULTS}

Of the 256 patients $45.7 \%$ were males and 54.3 $\%$ were females. $227(88.7 \%)$ had bilateral SNHL. Majority of diabetics are in the age group of 4060 years (Around 61\%). Around 27\% in 31-50 years of age have $\mathrm{SNHL}$, while it is around $44 \%$ in 51-60 years of age and it increases to around $72 \%$ at $61-70$ years of age (Table 1 ). Thus the prevalence of SNHL within each age group increases as the age group increases and the results are statistically significant. 
than 10 years. $20.5 \%$ of study population who had DM for less than two years had SNHL. The prevalence increased to $25 \%, 68.8 \%$, and $70.9 \%$ respectively for those who had diabetic duration between 2-5 years, 5-10 years and more than 10 years. The prevalence of SNHL increases with increase in duration of diabetics and the results are statistically significant

Table 3: Association between Diabetic Duration and prevalence of Sensorineural hearing loss.

\begin{tabular}{|c|c|c|c|c|c|c|c|}
\hline \multirow{2}{*}{$\begin{array}{l}\text { Duration } \\
\text { of DM }\end{array}$} & \multicolumn{2}{|c|}{ Diabetics } & \multicolumn{2}{|c|}{ Diabetics with SNHL } & \multirow{2}{*}{$\begin{array}{c}\text { Chi-square } \\
\text { value }\end{array}$} & \multirow{2}{*}{ P Value } & \multirow{2}{*}{$\begin{array}{l}\text { Prevalance withir } \\
\text { the duration }\end{array}$} \\
\hline & Frequency & $\%$ & Frequency & $\%$ & & & \\
\hline$<2$ years & 73 & 28.52 & 15 & 14.15 & \multirow{4}{*}{55.7} & \multirow{4}{*}{$P<0.00001$} & 20.55 \\
\hline 2-5 years & 83 & 32.43 & 21 & 19.82 & & & 25.3 \\
\hline $5-10$ years & 45 & 17.57 & 31 & 29.24 & & & 68.8 \\
\hline$>10$ years & 55 & 21.48 & 39 & 36.79 & & & 70.9 \\
\hline
\end{tabular}

Table 4: Association between $\mathrm{HbA1C}$ and Sensorineural hearing loss in diabetics.

\begin{tabular}{|c|c|c|c|c|c|c|c|}
\hline \multirow{2}{*}{ HbA1c Levels } & \multicolumn{2}{|c|}{ Diabetics } & \multicolumn{2}{|c|}{ Diabetics with SNHL } & \multirow{2}{*}{$\begin{array}{c}\text { Chi-square } \\
\text { value }\end{array}$} & \multirow{2}{*}{ P Value } & \multirow{2}{*}{$\begin{array}{c}\text { Prevalance within } \\
\text { the duration }\end{array}$} \\
\hline & Frequency & $\%$ & Frequency & $\%$ & & & \\
\hline$<7$ & 107 & 41.8 & 19 & 17.93 & \multirow{3}{*}{72.357} & \multirow{3}{*}{$P<0.00001$} & 17.76 \\
\hline $07-08$ & 94 & 36.72 & 39 & 36.79 & & & 41.19 \\
\hline$>8$ & 55 & 21.48 & nte 48 rat & 45,28 & & & 87.27 \\
\hline
\end{tabular}

As shown in table 4 , only $41 \%$ of the study population who had DM were under control. While all others were not under optimal control. The prevalence of DM was only $17.76 \%$ in those who were under control while it was around $41 \%$ in those who had $\mathrm{HbA1C}$ levels between 7-8 and it was $87.27 \%$ in those who had $\mathrm{HbA} 1 \mathrm{C}$ more than 8.

\section{DISCUSSION}

This cross-sectional study was carried out to study the prevalence of sensorineural hearing loss(SNHL) among Type II DM patients and to study the association between age, duration of $\mathrm{DM}$ and $\mathrm{HbA1C}$ levels with SNHL in India.

The prevalence of SNHL in diabetics is $41.4 \%$. In a study done by Kavitha and Saima [13] in Jabalpur the prevalence of SNHL was $33.7 \%$. Higher prevalence was reported by Swati et al in Gujarat(73\%), Anirudh and Ramesh [2] and shafee et at [15] in Karnataka(62.5\%).

Around $88.7 \%$ had bilateral hearing loss. Since microangiopathy is usually generalized and affects bilateral cochlea, the hearing loss due to this cause is also bilateral. In a study done by mozoffari et al [1] bilateral hearing loss is around $67 \%$.

The prevalence of SNHL within each age group increases as the age group increases and the results are statistically significant. Similar results were observed in many other studies [2,1418]. The prevalence of SNHL increases with increase in duration of diabetics and the results are statistically significant. Similar results were obtained in many other studies $[1,2,13,15,17$ 20].
Few studies have observed no relation between duration and SNHL [14, 16,21-24].

The prevalence of SNHL was higher in those who did not have control over diabetes. Similar results were observed by Anirudh and Ramesh [2], Shafee et al [15] and Pemmiah and Srinivas [20]. The two mechanisms by which hearing loss occurs in diabetes are diabetic angiopathy and neuropathy. Microangiopathy due to hyperglycemia affects the highly vascular cochlea along with hypoxia to nerve fibres, resulting in loss of nerve fibres and demyelination. Angiopathy along with vascular thickening results in accumulation of toxins in the endolymph causing hair cell dysfunction. Neuropathy is a result of secondary degeneration of vestibule cochlear nerve due to endothelial proliferation and accumulation of glycoproteins in the capillary basement membranes. As these changes are detrimental over time and glucose levels, the duration of diabetes and glycemic control are influential in determining degree and pattern of hearing loss [15,16,21].

\section{CONCLUSION}

There is a strong association between diabetes and SNHL. The higher the age, the longer the 
duration of DM and more poor glycemic control are contributing factors for the increased prevalence. Though the pathogenesis of SNHL in diabetes is not so clear, the role of DM in SNHL is clear. Hence proper glycemic control in diabetics must be ensured to prevention.

\section{REFERENCES}

[1]. M. Mozaffari, A. Tajik, N. Ariaei, F. Ali-Ehyaii and H. Behnam. Diabetes mellitus and sensorineural hearing loss among non-elderly people. Eastern Mediterranean Health Journal 2010;16(9):947-52.

[2]. Tiwari A, Mudhol RS. Prevalence of sensorineural hearing loss among type-Il diabetes mellitus patients attending KLES Dr. Prabhakar Kore Hospital and MRC: A cross-sectional study. Indian J Health Sci Biomed Res 2018;11:165-9.

[3]. WHO: Diabetes. [Internet]. 30 October 2018. [cited 10 March 2020]. Available from https:// www.who.int/news-room/fact-sheets/detail/diabetes.

[4]. WHO: Deafness and hearing loss, [Internet]. 20 March 2019. [cited 10 March 2020]. Available from https://www.who.int/news-room/fact-sheets/detail/deafness-and-hearing-loss.

[5]. Fukushima H, Cureoglu S, Schachern PA, Paparella MM, Harada T, Oktay MF, et al. Effects of type 2 diabetes mellitus on cochlear structure in humans. Arch Otolaryngol Head Neck Surg 2006;132:934 8.

[6]. Anindita R, Adnan A, Munir D, Syafril S, Ashar T. Comparison of Sensorineural Hearing Loss Degree between Controlled and Uncontrolled Type 2 Diabetes Mellitus Patients. Int J Sci Stud 2018;6(8):1-5.

[7]. Thiago Hernandes Diniz and Heraldo Lorena Guida, Hearing Loss in Patients with Diabetes Mellitus. Braz J Otorhinolaryngol. 2009;75(4):573-8

[8]. Friedman SA., Schulman RH, Weiss S. Hearing and diabetic neuropathy. Arch Intern Med 1975; 135: 573-6.

[9]. Tay HL, Ray N, Ohri R, Fronntko NJ. Diabetes mellitus and hearing loss. Clin Otolaryngol 1995; 20: 130-4.

[10]. Jorgensen MB, Buch NH. Studies on inner-ear and cranial nerves in diabetes. Acta Otolaringol. (Stockh.) 1961; 107: 179-82.

[11]. Dalton DS, Klein R, Klein BEK, Moss SE, Cruickshanks KJ. Association of NIDDM and hearing loss; Diabetes Care 1998; 21(9): 1540-4.

[12].Dr.Mohammed Shafeeq, Dr.Mohammed N A, Dr.Gangadhara Somayaji Dr.Mubeena, Mr.Hebin H Kallikkadan. Sensorineural hearing loss in Type 2 diabetes mellitus. IOSR Journal of Dental and Medical Sciences 2015;14(11):56-61.
[13]. Sachdeva K, Azim S. Sensorineural hearing loss and type II diabetes mellitus. Int J Otorhinolaryngol Head Neck Surg 2018;4:499-507.

[14]. Dadhich S, Jha SG, Sinha V, Samanth TU. A prospective, observational study of incidence of sensory neural hearing loss in diabetes mellitus patients. Indian J Otol 2018;24:80-2.

[15].Dr.Mohammed Shafeeq, Dr.Mohammed N A , Dr.Gangadhara Somayaji, Dr.Mubeena, Mr.Hebin H Kallikkadan. Sensorineural hearing loss in Type 2 diabetes mellitus. IOSR Journal of Dental and Medical Sciences 2015;14(11):56-61.

[16]. Cullen, J., \& Cinnamond, M. (1993). Hearing loss in diabetics. The Journal of Laryngology \& Otology, 107(3), 179-182.

[17]. J.L. Trevino-González , D.I. Campuzano-Bustamante , O. Flores-Caloca , R. Santos-Lartigue, M.J. VillegasGonzález Jr. Prevalence of sensorineural hearing loss in children and adolescents with diabetes mellitus. Medicina Universitaria. 2015; 17(68) :133137.

[18]. Ferrer JP, Birrun O, Lorent J, Conget JI, España R, Esmaltjs E, Gomis R. Auditory function in young patients with type 1 diabetes mellitus. Diabetes Res Clin Pract 1991; 11(1): 17-22

[19]. Friedman SA., Schulman RH, Weiss S. Hearing and diabetic neuropathy. Arch Intern Med 1975; 135 : 573-6.

[20]. Pemmaiah KD, Srinivas DR. Hearing loss in Diabetes Mellitus. International Journal of Collaborative Research on Internal Medicine \& Public Health. 2011; 3(10):725-731.

[21]. Samelli AG, Santos IS, Moreira RR, Rabelo CM, Rolim LP, Bensenõr IJ, Lotufo PA. Diabetes mellitus and sensorineural hearing loss: is there an association? Baseline of the Brazilian Longitudinal Study of Adult Health (ELSA-Brasil). Clinics (Sao Paulo). 2017 Jan $1 ; 72(1): 5-10$.

[22]. Cullen JR, Cinnamond MJ. Hearing loss in diabetics. The journal of Laryngology and Otology 1993; 107: 179-82.

[23]. Dalton DS, Klein R, Klein BEK, Moss SE, Cruickshanks KJ. Association of NIDDM and hearing loss; Diabetes Care 1998; 21(9): 1540-4.

[24]. Jorgensen MB, Buch NH. Studies on inner-ear and cranial nerves in diabetes. Acta Otolaringol. (Stockh.) 1961; 107: 179-82.

How to cite this article: Hari Krishna. ASSOCIATION BETWEEN SENSORINEURAL HEARING LOSS AND TYPE II DIABETES MELLITUS. Int J Intg Med Sci 2020;7(3):888-891. DOI: 10.16965/ijims.2020.103 